\title{
KAMPANIA WYBORCZA 1989 ROKU JAKO PRZYKŁAD KAMPANII PREMODERNIZACYJNEJ
}

ABSTRACT The 1989 parliamentary election campaign in Poland as an example of pre-modern campaigning

The significant change in the characteristics of political campaign communication has been acknowledged and examined by a plethora of scholars from various disciplines. A great deal of a scholarly community members have tried to coin their own theory, which would convincingly interpret this new reality. The aim of this article is to present specific features of pre-modern campaigning. The nature of this phenomenon is shown by analysing the 1989 parliamentary election campaign in Poland, which perfectly fits into the model described by Bogusława Dobek-Ostrowska, Mariusz Kolczyński and Janusz Sztumski. The author focuses primarily on campaign coordination and dominant channels for political campaigning. The campaign's financial resources and role of external professional consultants are also examined.

KEYWORDS Polish parliamentary election campaign, pre-modern campaigning, evolution of political campaign communication, campaign organization, 1989 


\section{WSTĘP}

Rok 1989 był dla Polski czasem doniosłych przemian ustrojowych, gospodarczych i społecznych. W ocenie Piotra Borowca stał siępodstawowym punktem odniesienia dla dziatań politycznych i myślenia spotecznego o transformacji w Polsce, (...) symbolicznym rozgraniczeniem dwóch, $w$ dużej części różnych, okresów historycznych ${ }^{1}$. Mimo upływu lat wydarzenia 1989 r. pozostają przedmiotem gorących dyskusji toczonych przez społeczeństwo, elity polityczne i środowiska naukowe. Część z nich dotyczy przebiegu kampanii wyborczej poprzedzającej „wybory kontraktowe”. W niniejszej pracy podjęto ten właśnie wątek, analizując wspomnianą kampanię przez pryzmat podziału na kampanie premodernizacyjne, modernizacyjne i postmodernizacyjne, zaproponowanego przez Davida M. Farrella, popularnego także w polskiej literaturze przedmiotu²

Informacje na temat kampanii można znaleźć w licznych utworach pamiętnikarskich i wspomnieniowych. Cennymi źródłami są wywiady rzeki z aktywistami ruchu solidarnościowego oraz przedstawicielami obozu rządowego. W'śód tego rodzaju prac należy wyróżnićzbiór wywiadów i komentarzy uczestników kampanii opracowany przez Romana Kałużę, wydany krótko po wyborach ${ }^{3}$, ujawniający kulisy pracy sztabowców opozycji i pozwalający zidentyfikować trudności, które napotykali podczas swojej działalności. Zagadnieniu poświęcono także wiele opracowań politologicznych, socjologicznych i historycznych ${ }^{4}$.

Równie popularnym tematem prac polskich i zagranicznych badaczy jest ewolucja kampanii wyborczych, która dokonała się na przestrzeni ostatniego półwiecza. Proces przemiany stylu działań kampanijnych został szybko zauważony przez badaczy anglosaskich i to właśnie do ich dorobku odwołuje się niniejszy artykuł. Szczególne znaczenie miały prace Davida M. Farrella i Pippy Norris, które wskazują na charakterystyczne cechy kampanii premodernizacyjnych, modernizacyjnych i postmodernizacyjnych. Koncepcja ta zdobyła uznanie polskich badaczy, odwoływali się do niej m.in. Bogusława Dobek-Ostrowska, Jan Garlicki, Mateusz Nieć, Robert Wiszniowski i Grzegorz Ignaczewski5. Głównym celem prac wymienionych autorów było ukazanie

1 P. Borowiec, Czas polityczny po rewolucji. Czas w polskim dyskursie politycznym po 1989 roku, Kraków 2013, s. 406.

2 Zob.np. M. Nieć, Komunikowanie polityczne w nowoczesnym państwie, Warszawa 2013, s. 102. Podział zaproponowany przez Farrella nie jest oczywiście jedyną teorią ewolucji kampanii wyborczych. Przykładowo Mateusz Nieć twierdził, że doświadczenia partii europejskich zdecydowanie lepiej odzwierciedla podział na kampanie partyjno-prasowe, partyjno-medialne oraz partyjno-marketingowe. Zob. tamże, s. 132-135.

3 Polska wybory'89, red. R. Kałuża, Warszawa 1989.

4 Zob. np. A. Piasecki, Wybory w Polsce 1989-2011, Kraków 2012; P. Codogni, Wybory czerwcowe 1989 roku. U progu przemiany ustrojowej, Warszawa 2012; J. Raciborski, Polskie wybory. Zachowania wyborcze spoteczeństwa polskiego 1989-1995, Warszawa 1997; Wybory 1989. Dokumenty strony solidarnościowo-opozycyjnej, t. 1: Kwatera Gtówna, red. I. Słodkowska, Warszawa 2009; A. Lipiński, Plebiscyt i odmowa. Studium terenowe reakcji wyborczej 1989 roku, Warszawa 1990.

5 Zob. np. B. Dobek-Ostrowska, Porozumienie czy konflikt. Politycy, media i obywatele $w$ komunikowaniu politycznym. Propaganda i PR w polityce, kampanie wyborcze, marketing i reklama polityczna, 
ewolucji sposobu prowadzenia polskich kampanii wyborczych. Celem niniejszego artykułu jest natomiast przeprowadzenie szczegółowej analizy wyborczej rywalizacji pomiędzy obozem solidarnościowym a władzami komunistycznymi w 1989 r. i ustalenie, który z trzech przywołanych rodzajów kampanii najlepiej opisuje jej przebieg.

Artykuł otwiera wprowadzenie teoretyczne (część 1) i historyczne (część 2). W częściach 3-6 przeprowadzono analizę siedmiu aspektów kampanii: czasu przygotowań, sposobu organizacji (część 3), stosowanych kanałów komunikowania, charakteru wydarzeń wyborczych (część 4), elektoratu (część 5), roli zewnętrznych agencji i konsultantów oraz wykorzystanych źródeł informacji (część 6) ${ }^{6}$. Zastosowanie pierwszego z wymienionych kryteriów polegało na określeniu, czy przygotowania do kampanii miały charakter długoterminowy, czy też prowadzone działania były wynikiem naprędce podejmowanych decyzji. Drugie z kryteriów dotyczyło tego, czy w kampanii z 1989 r. mieliśmy do czynienia z centralizacją, czy też decentralizacją działań wyborczych. Kryterium trzecie i czwarte sprowadzały się do określenia, jakimi kanałami kandydaci docierali do wyborców. Konieczne było przy tym ustalenie, czy główny nacisk położono na bezpośredni kontakt z elektoratem, czy też na promowanie kandydatów w radiu i telewizji oraz uczestnictwo w konferencjach prasowych. Zastosowanie piątego kryterium polegato na określeniu, do jakiego segmentu wyborców adresowane były kampanijne działania obu obozów. Podjęta została próba określenia, czy celem stron było pozyskanie nowych wyborców, czy też utrzymanie tzw. twardego elektoratu. Szóste kryterium oznaczało konieczność udzielenia odpowiedzi na pytanie o to, jak często rywalizujące strony korzystały z usług specjalistów od marketingu politycznego. Siódme wymagało określenia, czy działania konkurujących obozów miały charakter intuicyjny, czy też warunkowane były wynikami systematycznie przeprowadzanych badań opinii publicznej.

Należy podkreślić, że na ostateczny wynik „wyborów kontraktowych” wpłynęło wiele zmiennych i że ostatecznie to nie kampania wyborcza obu stron przesądziła o klęsce kandydatów reprezentujących ówczesną władzę. Czynnikiem decydującym były rezultaty komunistycznych rządów, m.in. głęboki kryzys gospodarczy, stale pogarszające się warunki bytowe i rosnące niezadowolenie społeczne? ${ }^{7}$. Wkrótce po wyborach w niemieckim tygodniku „Der Spiegel” ukazał się komentarz, w którym stwierdzono, że wynik czerwcowej elekcji jest udokumentowaniem 45-letniego sprawowania wtadzy przez komunistów $w^{8}$ W podobnym tonie wypowiadała się część działaczy lokalnych struktur

Warszawa 2009; J. Garlicki, Komunikowanie polityczne - od kampanii wyborczej do kampanii permanentnej, „Studia Politologiczne” 2010, vol. 16; M. Nieć, Komunikowaniepolityczne...; R. Wiszniowski, Marketing wyborczy. Studium kampanii wyborczych $w$ systemach prezydenckich i semiprezydenckich (Finlandia, Francja, Polska, Stany Zjednoczone), Warszawa-Wrocław 2000; G. Ignaczewski, Specyfika marketingu politycznego w Polsce, Torun 2005.

$6 \quad$ R. Wiszniowski, Marketing wyborczy..., s. 104-105.

7 Problem przyczyn załamania rządów komunistycznych wielokrotnie podejmował Antoni Dudek. Zob. np. A. Dudek, Reglamentowana rewolucja. Rozktad dyktatury komunistycznej w Polsce 1988-1990, Kraków 2004; tenże, Kryzys systemu komunistycznego w Polsce lat osiemdziesiątych, „Pamięć i Sprawiedliwość" 2007, nr 1 (11), s. 105-118.

8 A. Andrusiewicz, Polska 1980-1990. Kalendarz dekady przetomu, Rzeszów 1995, s. 128. 
PZPR, którym skala wyborczej porażki uświadomiła, że większość spoteczeństwa ma dośćpartii takiej jak dotą, obecnego stylu sprawowania wtadzy i gospodarowania?.

\section{POJĘCIE KAMPANII WYBORCZEJ}

Na potrzeby niniejszego artykułu przyjęto definicję kampanii wyborczej, którą posługuje się Dobek-Ostrowska. Jej zdaniem za kampanię należy uznać wyodrębniony fragment komunikowania politycznego, podczas którego aktorzy polityczni intensyfikuja. dziatania komunikacyjne, $w$ celu zdobycia maksymalnego poparcia politycznego dla podmiotów podejmujacych te dziatania. Jest to wydzielona faza procesu wyborczego obejmująca okres pomiędzy ogtoszeniem decyzji o przeprowadzeniu wyborów, do uregulowanego przepisami dnia poprzedzajacego dzień gtosowania ${ }^{10}$. Jak podkreśla Dobek-Ostrowska, to w gestii państwa leży regulacja prawna takich kwestii, jak zasady finansowania i prowadzenia kampanii oraz dostęp podmiotów rywalizacji do mediów publicznych. Stąd też ramy prawne działań kampanijnych mogą różnić się w zależności od systemu wyborczego i politycznego.

Farrell i Norris zwracają uwagę na stopniowy proces przemiany stylu działań kampanijnych. Owa zmiana polegała na przejściu od tzw. kampanii premodernizacyjnych do kampanii modernizacyjnych i postmodernizacyjnych ${ }^{11}$. Zdaniem przywołanych autorów możliwe jest zakreślenie ram czasowych dla wszystkich trzech faz. Należy przy tym wyraźnie podkreślić, że model zaprezentowany przez Farrella i Norris miał na celu ukazanie zmian, które zachodziły w USA i krajach zachodnioeuropejskich, a zatem zarysowane przez nich ramy czasowe odnoszą się tylko i wyłącznie do tych państw. W krajach niedemokratycznych (a takim była wówczas Polska) wybory nie decydują o tym, kto będzie sprawował władzę. Elity rządzące nie przywiązują więc równie dużej wagi do podnoszenia efektywności działań kampanijnych.

Era kampanii premodernizacyjnych, której początków należy dopatrywać się już w XIX w., trwała przynajmniej do początku lat 50. XX w. Przytaczając badania Farrella, Wiszniowski wskazuje, że charakterystyczną cechą premodernizacyjnych kampanii wyborczych był wysoki stopień decentralizacji, który pociągał za sobą niski poziom standaryzacji kampanii danej partii w skali catego kraju ${ }^{12}$. Zadania kampa-

9 S. Rosenbaum, Miejskie struktury PZPR województwa katowickiego wobec wyborów czerwcowych 1989 r., [w:] Wybory i referenda w PRL, red. S. Ligarski, M. Siedziako, Szczecin 2014, s. 388.

10 B. Dobek-Ostrowska, Porozumienie czy konflikt..., s. 132.

11 Problem stopniowej ewolucji stylu działań kampanijnych stał się tematem wielu publikacji Davida M. Farrella. Kompleksowy opis przywołanej typologii można znaleźć w pracach: D. M. Farrell, Campaign strategies and tactics, [w:] Comparing democracies. Elections and voting in global perspective, red. L. LeDuc, R. Niemi, P. Norris, Thousand Oaks 1996; tenże, P. Webb, Political parties as campaign organizations, [w:] Parties without partisans. Political change in advanced industrial democracies, red. R. Dalton, M. Wattenberg, Oxford 2000. Temat ten wielokrotnie poruszała również Pippa Norris. Zob. np. P. Norris, Electoral change in Britain since 1945, Oxford 1997; taż, A Virtuous circle. Political communications in postindustrial societies, Cambridge 2000.

12 R. Wiszniowski, Marketing wyborczy..., s. 103. 
nijne realizowane były głównie przez członków partii, kandydatów i wolontariuszy. W niewielkim stopniu korzystano wówczas z pomocy wyspecjalizowanych agencji i konsultantów ${ }^{13}$. Kandydaci dobierani przez partię prowadzili stosunkowo krótką, spontaniczną i opartą na intuicji kampanię, zaś dominującą metodą komunikacji była agitacja ${ }^{14}$. Kampanie premodernizacyjne opierały się na bezpośrednich kontaktach kandydatów z wyborcami na szczeblu lokalnym, które obliczone były na podtrzymanie tzw. twardego elektoratu ${ }^{15}$. Obok bezpośrednich spotkań z wyborcami, podczas których rozdawano broszury i ulotki przybliżające sylwetki kandydatów i ich programy, istotnym kanałem komunikacji z elektoratem była reklama wizualna w postaci plakatów umieszczanych w miejscach publicznych ${ }^{16}$. Kolejną istotną cechą kampanii w stylu premodernizacyjnym jest drugoplanowa rola kandydata - kluczowa dla decyzji wyborcy była partyjna przynależność osoby ubiegającej się o mandat ${ }^{17}$. Istotnym wskaźnikiem tego, z jakim rodzajem kampanii mamy do czynienia, jest kryterium finansowe. Kampanie premodernizacyjne były zdecydowanie mniej kosztowne niż kampanie postmodernizacyjne.

Rozwój środków masowego przekazu oraz zmiany społeczne, które zaszły w połowie $\mathrm{XX}$ w., pociągnęły za sobą przekształcenia w dziedzinie komunikowania politycznego. Z chwilą, w której politycy odkryli siłę mediów masowych, rozpoczęła się era kampanii modernizacyjnych. Były one centralnie koordynowane przez liderów partyjnych, co uruchomiło proces ujednolicania działań promocyjnych partii w skali ogólnokrajowej ${ }^{18}$. Nowością było zaangażowanie profesjonalnych doradców, specjalistów w swoich dziedzinach. Przeważnie byli to wewnętrzni konsultanci, powiązani ze strukturami partyjnymi, jednak angażowano również niezależnych doradców zewnętrznych ${ }^{19}$. Kampanie modernizacyjne opierały się na skierowanych do ogółu wyborców działaniach długoterminowych. Wzrosła intensywność wykorzystania środków masowego komunikowania. Media masowe zaczęły pełnić funkcję pośrednika między wyborcami a kandydatami, okazały się również doskonałym nośnikiem reklamy politycz$n^{20}{ }^{20}$. Na szeroką skalę stosowano również systematyczne badania opinii publicznej. Konieczność korzystania z usług specjalistów, przeprowadzania systematycznych badań rynku i zakupu czasu antenowego doprowadziła do znacznego wzrostu wydatków, co skłoniło Farrella do nazwania nowych kampanii kapitałochłonnymi ${ }^{21}$. Jeśli chodzi

13 B. Dobek-Ostrowska, Profesjonalizacja kampanii wyborczych, [w:] Kampania wyborcza. Marketingowe aspekty komunikowania politycznego, taż, Wrocław 2005, s. 20.

14 M. Kolczyński, J. Sztumski, Marketing polityczny. Ksztattowanie indywidualnych i zbiorowych opinii, postaw i zachowań, Katowice 2003, s. 97.

15 Tamże.

16 B. Dobek-Ostrowska, Porozumienie czy konflikt..., s. 137.

17 Tamże.

$18 \quad$ R. Wiszniowski, Marketing wyborczy..., s. 106.

19 B. Dobek-Ostrowska, Profesjonalizacja kampanii..., s. 20.

20 M. Kolczyński, J. Sztumski, Marketing polityczny..., s. 97.

$21 \quad$ R. Wiszniowski, Marketing wyborczy..., s. 108. 
o strukturę kosztów, to znaczną część środków przeznaczano na promocję w mediach masowych - przede wszystkim w telewizji.

Lata 80. XX w. przyniosły kolejne przeobrażenia sposobu prowadzenia kampanii wyborczych. Kampanie postmodernizacyjne, podobnie jak modernizacyjne, bazują na działaniach wysoko wykwalifikowanego zespołu, wyspecjalizowanego w konkretnych, bardzo wąskich dziedzinach ${ }^{22}$. Jednak w tym modelu konsultanci nie tylko realizują kampanię w sposób techniczny, ale również aktywnie uczestniczą w tworzeniu produktu politycznego. Decydują, jaka oferta polityczna jest budowana, które wątki programu są akcentowane najbardziej, a także jakie treści należy wprowadzić do programu. Partia przekazuje część pracy nad „produktem” w ręce profesjonalistów. Proces ten można określić mianem decentralizacji działań. Tak wysoki stopień zaangażowania konsultantów politycznych w proces organizowania i kontrolowania kampanii wyborczej sprawia, że odpowiedzialność za charakter i ostateczny wynik kampanii zostaje scedowana na niezależnych doradców ${ }^{23}$. Do charakterystycznych cech kampanii postmodernizacyjnych można również zaliczyć wydłużenie i nasilenie komunikowania politycznego. W ocenie Garlickiego stopniowo (...) dochodzi do zastapienia kampanii wyborczej kampania permanentna, a komunikowaniepolityczne przestaje być prowadzone gtównie w okresie wyborów czy w czasie „okoto wyborczym”, ale staje się procesem realizowanym nieprzerwanie, choć oczywiście ze zmienna intensywno$s c i q^{24}$. Obrana strategia zorientowana jest na pozyskanie nowych wyborców, dlatego bardzo intensywnie prowadzone są badania opinii publicznej. Obok mediów tradycyjnych stosuje się także nowe kanały komunikacji ${ }^{25}$. Jeśli obserwujemy przesunięcie wydatków z rynku telewizyjnego na rynek nowych mediów (internetowy), to możemy założyć, że kampania modernizacyjna zaczyna przeobrażać się w kampanię postmodernizacyjną.

\section{WYBORY PARLAMENTARNE W 1989 R. - OKOLICZNOŚCI HISTORYCZNE}

Wybory parlamentarne w czerwcu 1989 r. były rezultatem okrąglostołowych porozumień, zawartych między kierownictwem Polskiej Zjednoczonej Partii Robotniczej (PZPR) a solidarnościowym obozem opozycyjnym. W wyniku ustaleń umawiających się stron, po blisko czterech dekadach nieobecności, do polskiego systemu politycznego powrócily dwa istotne organy - Senat oraz instytucja prezydenta. Opozycja zaakceptowała wyposażenie urzędu głowy państwa w szerokie uprawnienia, w zamian za całkowicie wolne wybory do izby wyższej parlamentu. Ponadto ustalono, że $65 \%$ miejsc w Sejmie będzie zarezerwowane dla członków PZPR i ich sojuszników, a o pozostałe 35\% rywalizować będą kandydaci bezpartyjni ${ }^{26}$.

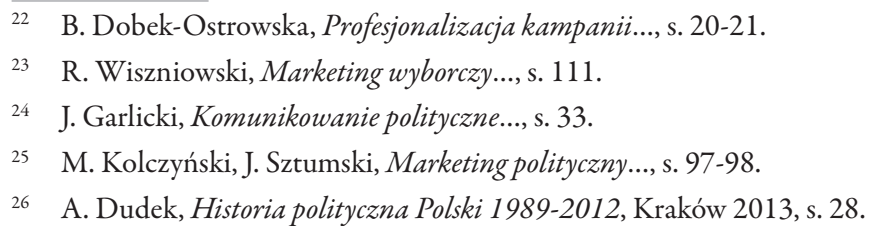


Szybki spadek społecznego poparcia dla rządu Mieczysława Rakowskiego oraz świadomość ogromu trudności organizacyjnych, z jakimi będą musieli zmierzyć się polityczni konkurenci, były czynnikami, które wyraźnie wpłynęły na kształt kalendarza wyborczego ${ }^{27}$. Kierownictwo PZPR zdawało sobie sprawę z tego, że pośpiech działa na korzyść obozu rządzącego, zmierzano więc do maksymalnego skrócenia kampanii wyborczej, starając się zaskoczyć stronę solidarnościową, która nie posiadała w pełni rozwiniętych struktur ${ }^{28}$. Decyzja o ich rozbudowie zapadła dopiero w pierwszej połowie kwietnia, jednak proces ten szybko nabrał dynamicznego charakteru - początkowo utworzono regionalne Komitety Obywatelskie na terenie każdego województwa, następnie w dzielnicach i na osiedlach miast oraz w mniejszych miejscowościach ${ }^{29}$. Teresa Astramowicz-Leyk przytaczała dwa podstawowe powody, które skłoniły opozycję do zaakceptowania niezbyt korzystnego, czerwcowego terminu wyborów ${ }^{30}$. Po pierwsze, „Solidarność" starała się maksymalnie wykorzystać sprzyjający okres rządów Michaiła Gorbaczowa na Kremlu. Po drugie, opozycyjni działacze zdawali sobie sprawę z podziałów, jakie istniały w polskiej elicie władzy, i żywili obawę, że inicjatywę przejmie frakcja radykałów, co oznaczałoby zerwanie porozumienia i zagrożenie dla procesu demokratyzacji ${ }^{31}$.

Dnia 13 kwietnia 1989 r. Rada Państwa ogłosiła termin przeprowadzenia wyborów. Był to formalny początek kampanii wyborczej ${ }^{32}$. Pierwsza tura wyborów do obu izb parlamentu miała się odbyć 4 czerwca, natomiast druga tura została wyznaczona na dzień 18 czerwca. Kampania miała więc być bardzo krótka, co działało na niekorzyść opozycji. Przedstawiciele strony rządowej założyli, że opozycja jest silna tylko w większych ośrodkach miejskich. Sytuacja zupełnie inaczej miała wyglądać na prowincji, czyli tam, gdzie „Solidarność" miała niewielkie wpływy. Mając to na uwadze, w wyborach do Senatu zastosowano metodę większościową i dwumandatowe okręgi wyborcze, pokrywające się z granicami ówczesnych 49 województw. Dzięki temu powstała sytuacja bardzo korzystna dla obozu rządzącego - małym województwom rolniczym przypadła taka sama liczba senatorów, co bastionom opozycji33. Ordynacja wyborcza do Sejmu z góry określała podział miejsc i zapewniała PZPR i jej sojusznikom dominację w izbie niższej parlamentu.

27 Tenże, Decydujace miesiace. Polska, kwiecień-sierpień 1989, [w:] Polska 1986-1989: koniec systemu. Materiaty międzynarodowej konferencji, Miedzeszyn 21-23 października 1999, t. 1: Referaty, red. P. Machcewicz, Warszawa 2002, s. 118.

Tenże, Historia polityczna Polski..., s. 34.

T. Astramowicz-Leyk, Kampania wyborcza 1989 roku, [w:] Polska - 25 lat transformacji systemowej. Polityka, gospodarka, bezpieczeństwo, red. taż, W. Tomaszewski, Olsztyn 2014, s. 86.

31 Tamże.

32 J. Raciborski, Polskie wybory..., s. 30.

33 A. Piasecki, Wybory w Polsce..., s. 14 . O próbach manipulacji wynikiem wyborów, które podejmowano na etapie tworzenia okręgów i podziału mandatów, pisał również Adam Dziuba. Zob. A. Dziuba, Kampania wyborcza i wybory w województwie katowickim, [w:] Upadek systemu komunistycznego na Górnym Ślasku. Wokót przemian 1989 roku w województwach katowickim i opolskim, red. tenże, S. Rosenbaum, Katowice 2010, s. 280. 
Nowe przepisy prawa wyborczego zakładały również utworzenie tzw. listy krajowej zawierającej nazwiska czołowych działaczy obozu rządzącego. Jej upadek wymusił zmianę ordynacji w okresie pomiędzy pierwszą a drugą turą wyborów parlamentarnych ${ }^{34}$.

Obozowi solidarnościowemu narzucono trudne warunki wyborczego pojedynku. Kontrola nad całym aparatem propagandowym i znaczne jak na tamte czasy zaplecze finansowe dawało partyjnym oficjelom złudne poczucie przewagi nad konkurentem ${ }^{35}$. Pełen optymizmu aktyw partyjny zdawał się nie dostrzegać, że tak poważna zmiana reguł gry wymaga porzucenia starych wzorców i większego zaangażowania w wyborczą rywalizacje $e^{36}$. Kształt wyborczego kalendarza wymusił szybkie tempo kampanijnych działań i pozostawiał niewiele czasu na aktywizację biernych członków partii. Przygotowania do starcia wyborczego miały zatem charakter krótkoterminowy, wiele decyzji podejmowano naprędce, a cała kampania sprawiała wrażenie niedopracowanej i chaotycznej ${ }^{37}$. Żywiołowy charakter podejmowanych działań uchwycił Timothy Garton Ash, który zauważył, że działania strony opozycyjnej można określić mianem festiwalu narodowej improwizacji $i^{38}$.

\section{ORGANIZACJA I KOORDYNACJA KAMPANII}

Odzwierciedleniem politycznego konsensusu wypracowanego podczas obrad Okrągłego Stołu były dwie ustawy ordynacyjne, przyjęte przez Sejm 7 kwietnia 1989 r. ${ }^{39}$ Zgodnie z zapisami Ordynacji wyborczej do Sejmu Polskiej Rzeczypospolitej Ludowej X kadencji, na lata 1989-1993 zdecydowana większość członków niższej izby parlamentu miała zostać wybrana $\mathrm{w}$ wielomandatowych okręgach wyborczych. Jednocześnie utrzymano instytucję krajowej listy wyborczej ${ }^{40}$. O liczbie i granicach okręgów wyborczych

34 Więcej informacji na temat listy krajowej i późniejszej zmiany ordynacji zob. A. Małkiewicz, Wybory czerwcowe 1989, Warszawa 1994.

35 Marian Orzechowski, [w:] Koniec epoki. Wywiady Maksymiliana Berezowskiego, red. M. Berezowski, Warszawa 1991, s. 153.

36 Ułomne podejście partyjnego aparatu podkreślał sam Wojciech Jaruzelski, który przyczyn wyborczej klęski dopatrywał się w indolencji, pasywności, przekonaniu, że i tak wygramy, bo się przyzwyczailiśsmy do wygrywania zawsze. Zob. Wojciech Jaruzelski, [w:] Koniec epoki..., s. 32.

37 R. Wiszniowski, Modernizacja kampanii politycznej na przyktadzie parlamentarnych kampanii wyborczych w Polsce z lat dziewięćdziesiatych, ze szczególnym uwzględnieniem PSL, [w:] W kręgu historii i politologii. Ksiegga jubileuszowa dedykowana Profesorowi Stanistawowi Dąbrowskiemu, red. K. Dziubka i in., Wrocław 2002, s. 399.

38 T. G. Ash, Wiosna obywateli. Rewolucja 1989 widziana w Warszawie, Budapeszcie, Berlinie i Pradze, przeł. A. Husarska, Londyn 1990, s. 17. O spontanicznym charakterze kampanii i doraźności podejmowanych działań, zob. W. Łobodziński, Bytem szefem zespotu promocyjnego na Mokotowie, [w:] Polska wybory..., s. 121-133; T. G. Ash, Polskie problemy, [w:] Polska wybory..., s. 85-86.

39 A. Sokala, Wybory parlamentarne - czerwiec 1989 r., „Przegląd Sejmowy” 2009, nr 3 (92), s. 48. Zob. też: R. Chruściak, System wyborczy i wybory w Polsce 1989-1998. Parlamentarne spory i dyskusje, Warszawa 1999, s. 11-24.

40 A. Sokala, Wybory parlamentarne..., s. 49. 
oraz dokładnej liczbie mandatów przypisanych do poszczególnych okręgów decydowała Rada Państwa ${ }^{41}$. Ostatecznie utworzono 108 okręgów wyborczych, w których wybierano od dwóch do pięciu posłów. Rada ustaliła także, że 35 posłów zostanie wybranych z krajowej listy wyborczej ${ }^{42}$. Jak wspomniano wcześniej, zgodnie z zapisami ordynacji wszyscy senatorowie mieli zostać wybrani w dwumandatowych okręgach wyborczych, które pokrywały się z granicami 49 województw (wyjątek stanowiły okręgi warszawski i katowicki, którym przypisano po trzy mandaty senatorskie) ${ }^{43}$. Pośpiesznie uchwalona ordynacja do Sejmu nadawała uprawnienia do zgłaszania kandydatów partiom oraz wyborcom w liczbie co najmniej 3 tys. Ordynacja do Senatu zakładała, że każdy kandydat na senatora musi uzyskać poparcie wyborców w formie 3 tys. podpisów ${ }^{44}$. Obóz solidarnościowy i strona rządowa przyjęły dwie różne strategie już na etapie zgłaszania kandydatów.

Ciałem koordynującym kampanię wyborczą opozycji, zgodnie z uchwałą Krajowej Komisji Wykonawczej, został Komitet Obywatelski przy Przewodniczącym NSZZ „Solidarność" Lechu Wałęsie (Komitet Obywatelski) ${ }^{45}$. Podporządkowano mu wszystkie komitety wojewódzkie i regionalne, których zadaniem było przygotowanie list kandydatów do parlamentu. Na podstawie tych propozycji Komitet Obywatelski opracował krajową listę kandydatów, zaakceptowaną następnie przez „Solidarność” i samego Wałęsę ${ }^{46}$. Aby uniknąć rywalizacji między kandydatami obozu solidarnościowego i zapobiec zjawisku rozproszenia głosów, Komitet Obywatelski zadecydował, że liczba wystawionych kandydatów będzie odpowiadała liczbie miejsc do zdobycia ${ }^{47}$. Wszystkie przywołane powyżej uwagi, dotyczące sposobu koordynowania kampanijnych działań opozycji, skłoniły Jacka Raciborskiego do określenia ich mianem kampanii silnie scentralizowanej, opartej na hierarchicznych strukturach ${ }^{48}$.

Działania partii rządzącej znacząco różniły się od taktyki, którą przyjęła strona solidarnościowa. Na etapie zgłaszania kandydatów do Sejmu i Senatu dopuszczono bowiem do decentralizacji procedur - kierownictwo PZPR zadowoliło się decydującym głosem jedynie przy układaniu listy krajowej. W obrębie koalicji rządowej rozpoczęła się więc wewnętrzna rywalizacja, która w znacznym stopniu utrudniała działania promocyjne ${ }^{49}$. Efektem była sytuacja, w której o jeden mandat starało się kilku kandydatów strony rządowej, nawet mimo sprzeciwu aparatu partyjnego ${ }^{50}$. Podstawowe założenia

\footnotetext{
$41 \quad$ R. Chruściak, System wyborczy..., s. 19.

42 Tamże.

43 A. Sokala, Wybory parlamentarne..., s. 50.

44 A. Piasecki, Wybory w Polsce..., s. 14-15.

45 J. Raciborski, Polskie wybory..., s. 30; Zob. też P. Codogni, Wybory czerwcowe..., s. 114.

J. Raciborski, Polskie wybory..., s. 30; Zob. też: I. Słodkowska, Organizacja strony solidarnościowo-opozycyjnej w kampanii wyborczej 1989 roku, [w:] Wybory 1989. Dokumenty..., s. 13.

47 J. Raciborski, Polskie wybory..., s. 30.

48 Tamże.

49 Jerzy Urban, [w:] Koniec epoki..., s. 227.

so A. Małkiewicz, Wybory czerwcowe..., s. 34.
} 
kampanii opracował Wydział Polityczno-Organizacyjny Komitetu Centralnego. Plan działań został następnie zaakceptowany przez Biuro Polityczne KC PZPR. Podstawą programu była nierealistyczna koncepcja przeprowadzenia wyborów niekonfrontacyjnych ${ }^{51}$. Organizację i realizację kampanii na szczeblu centralnym powierzono Zygmuntowi Czarzastemu, który od grudnia 1988 r. piastował stanowisko sekretarza KC PZPR. Andrzej Małkiewicz zauważa, że odpowiedzialność za klęskę strony rządowej ponosi nie tylko Czarzasty ${ }^{52}$. Kampania była dziełem całego kierownictwa PZPR - za przygotowanie polityczne odpowiadał Józef Czyrek, natomiast za propagandę wyborczą Stanisław Ciosek. Małkiewicz wskazuje na ich brak zdecydowania i temperamentu oraz nieumiejętność oddziaływania publicznego. Partyjni działacze niezaznajomieni z regułami wyborczej walki mogli jedynie przyglądać się klęsce swojego obozu.

Powyższa analiza stopnia decentralizacji działań wyborczych wskazuje, że działania sztabowców opozycji oraz strony rządowej wpisują się w model kampanii typu premodernizacyjnego. Gdy spojrzymy na sposób, w jaki „Solidarność” formowała listy kandydatów, zauważymy kreacyjną funkcję struktur lokalnych. Podstawą listy ogólnopolskiej stały się bowiem spisy przygotowane przez komitety regionalne i wojewódzkie ${ }^{53}$. Paweł Kowalski podkreśla również, że ogólny program wyborczy opozycji stanowit pewien zarys określonej platformy ideowej i, jak każda tego typu deklaracja, zakreślit on jedynie granice, $w$ których regionalne komitety obywatelskie oraz poszczególni ich kandydaci mogli (choć nie musieli) prezentować swoje wtasne programy wyborcze ${ }^{54}$. Widać więc, że regionalne struktury cieszyły się znacznym zakresem swobody. Pewnym ograniczeniem tej wolności był płynący z centrali zakaz rywalizacji między kandydatami „Solidarności”. Narzucone rozwiązanie miało jednak przekonujące uzasadnienie - bliski termin wyborów i brak w pełni rozwiniętych struktur lokalnych ${ }^{55}$. Działania strony koalicyjnej również charakteryzują się wysokim stopniem decentralizacji. Partyjne centrum nie było w stanie opanować osobistych ambicji kandydatów i zapobiec zjawisku rozproszenia głosów, co w pewnym stopniu przyczyniło się do wyborczej porażki.

\section{STOSOWANE KANAŁY KOMUNIKOWANIA I CHARAKTER WYDARZEŃ WYBORCZYCH}

Podczas rokowań prowadzonych przy Okrągłym Stole stronie opozycyjnej udało się uzyskać obietnicę dostępu do mediów państwowych. Brak precyzyjnych zapisów w tej kwestii zmuszał przedstawicieli strony solidarnościowej do prowadzenia indywidual-

51 A. Dudek, Historia polityczna Polski..., s. 38.

52 A. Małkiewicz, Wybory czerwcowe..., s. 32.

53 P. Kowalski, To miasto Łódź się nazywa, [w:] Nasze 53 dni i dwa tygodnie. 4 czerwca '89, red. I. Śledzińska-Katarasińska, M. Sondej, Łódź 2009, s. 9.

54 Tamże, s. 17.

55 Zob. P. Kowalski, Proponowano nadzieje, [w:] Nasze 53 dni..., s. 128; S. Bratkowski, Gramy o swój los, [w:] Polska wybory..., s. 65. 
nych negocjacji z nieprzychylnie do niej nastawionymi władzami radia i telewizji ${ }^{56}$. Po raz kolejny uwidoczniła się ogromna dysproporcja sił między PZPR a opozycją $a^{57}$. Partia rządząca miała do dyspozycji cały aparat państwowy oraz sprawowała pełną kontrolę nad środkami masowego przekazu. Organizacja pracy państwowych stacji telewizyjnych i radiowych mieściła się w kompetencjach Komitetu do spraw Radia i Telewizji „Polskie Radio i Telewizja” (Radiokomitet). Podczas kampanii wyborczej w 1989 r. prezesem Radiokomitetu był Jerzy Urban, zaufany współpracownik Jaruzelskiego, ubiegający się o mandat poselski w ramach puli przeznaczonej dla kandydatów bezpartyjnych ${ }^{58}$. Programy „Solidarności” musiały spełniać wysokie wymagania w zakresie poziomu technicznego, pod rygorem niedopuszczenia ich do emisji. Dodatkowo wszelkie materiały podlegały kontroli ze strony cenzury - programy krótkie musiały być przedstawiane do akceptacji właściwego organu na 24 godziny przed emisją, materiały długie - na 48 godzin przed nadaniem. Nie było możliwości nadawania programów w czasie rzeczywistym ${ }^{59}$. Artur Janicki, odpowiedzialny za realizację kampanii telewizyjnej w Telewizji Kraków, tak wspomina swoją działalność w trakcie kampanii: Na najwyższym szczeblu (...) ustalono, że możemy sami redagować telewizyjne audycje wyborcze. Ale w takim razie nikt z pracowników TV nie może nam pomagać. Poza, oczywiście, pracownikami obstugujacymi urządzenia, przydzielone do realizacji. A byto nas dwóch (... ${ }^{60}$.

Komitet Obywatelski uzyskał dostęp do dwóch programów telewizyjnych. Jednym z nich była 45-minutowa audycja, emitowana raz w tygodniu. Programowi temu nie przydzielono konkretnej godziny ani nawet kanału. Audycję nadawano w jednym z dwóch programów, o różnej porze, bez uprzednich zapowiedzi ${ }^{61}$. Opozycja uzyskała również dostęp do ogólnopolskiego programu wyborczego, w którym przedstawiano sylwetki wszystkich kandydatów. Strona solidarnościowa musiała zadowolić się w tym wypadku 23\% czasu antenowego. Jeśli chodzi o audycje radiowe, to programy opozycji stanowiły zaledwie $32 \%$ czasu poświęcanego na audycje wyborcze ${ }^{62}$. Telewizyjne wystąpienia opozycji skupiały się na przedstawianiu celów „Solidarności”, prezentacji kandydatów Komitetu Obywatelskiego oraz informacjach o sposobie oddawania ważnego głosu. Nieskrywana niechęć ze strony państwowych instytucji oraz ingerencje cenzury w treść materiałów promocyjnych paradoksalnie służyły kandydatom opozycji ${ }^{63} . Z$ jed-

56 P. Codogni, Wybory czerwcowe..., s. 136.

57 O uprzywilejowanej pozycji strony rządowej i problemach organizacyjnych sztabu opozycji pisali m.in. Andrzej Paczkowski i Grzegorz Ignaczewski. Zob. A. Paczkowski, Od ffatszowanego zwyciestwa do prawdziwej klęski. Szkice do portretu PRL, Kraków 1999, s. 172; G. Ignaczewski, Specyfika marketingupolitycznego..., s. 56, 62 .

58 A. Dudek, Historia polityczna Polski..., s. 37.

59 P. Codogni, Wybory czerwcowe..., s. 136.

60 A. Janicki, Beczka radości i kilka tyżek dziegciu, [w:] Wybory '89 w Krakowie. Wspomnienia, relacje i dokumenty z kampanii wyborczej Matopolskiego Komitetu Obywatelskiego „Solidarnośc', red. T. Gąsowski, Kraków 1999, s. 33.

${ }^{61}$ P. Codogni, Wybory czerwcowe..., s. 136.

62 Tamże.

63 S. Kowalski, Narodziny III Rzeczypospolitej, Warszawa 1996, s. 22. 
nej strony skutecznie przyciągały one uwagę wyborców, z drugiej były wyraźnym dowodem na to, że próby kooptacji solidarnościowych liderów do istniejącego układu nie zakończyły się powodzeniem.

Przełomem w kampanii medialnej opozycji okazało się utworzenie „Gazety Wyborczej” (GW), która szybko stała się głównym organem prasowym strony solidarnościowej ${ }^{64}$. Formalnie dziennik należał do spółki „Agora”, utworzonej przez Zbigniewa Bujaka, Aleksandra Paszyńskiego i Andrzeja Wajdę. Pierwszy numer, który ukazał się 8 maja 1989 r. w nakładzie 150 tys. egzemplarzy, dostępny był jedynie w czterech dużych miastach - Warszawie, Lublinie, Kielcach i Radomiu ${ }^{65}$. Niski nakład i niewielki rozmiar dziennika wynikały z ograniczonej ilości papieru dostarczanego przez państwo. Trudności ze zdobyciem gazety rozwiązywali często sami czytelnicy - po przeczytaniu zwracano ją do kiosków lub raz zakupiony egzemplarz przekazywano dalej. Późniejsze zwiększenie nakładu do 370 tys. umożliwiło sprzedaż GW na terenie całego kraju, a nawet za jego granicami - specjalne wydania kierowane były do rozsianej po świecie Polonii ${ }^{66}$. "Gazeta” nie była jedynym organem prasowym sprzyjającym opozycji. Od 6 maja w Krakowie ukazywał się „Głos Wyborczy Solidarności”, a 2 czerwca wznowiono wydawanie „Tygodnika Solidarnośc”. Stanowisko redaktora naczelnego objął Tadeusz Mazowiecki ${ }^{67}$. Kandydatom opozycji poparcia udzielała również redakcja „Tygodnika Powszechnego”, pisma popularnego wśród polskiej inteligencji, liberalnych kręgów katolickich, przedstawicieli środowisk kultury i kształtującej się elity politycznej, który przez wielu traktowany był jako nieformalny organ prasowy środowisk opozycyjnych ${ }^{68}$. Jak podkreślał Władysław Kolasa, to właśnie tygodnik Jerzego Turowicza był pierwszym legalnie działającym polskim pismem, na którego łamach zamieszczono program wyborczy „Solidarności” oraz kompletne listy wyborcze ${ }^{69}$.

Problemów z dostępem do mediów państwowych nie miała strona rządowa. Artykuły przychylnych rządowi dziennikarzy prasowych obarczały "Solidarność" winą za złą sytuację gospodarczą państwa. W zamieszczaniu napastliwych tekstów przodowały „Trybuna Ludu”, „Życie Warszawy” i „Żołnierz Wolności”. W zamieszczanych tam artykułach opozycji zarzucano m.in. niedemokratyczne wyłanianie kandydatów, osłabianie mocy obronnej PRL, kupczenie Ziemiami Zachodnimi oraz uprawianie swoistego terroryzmu moralnego ${ }^{70}$. Prasa partyjna często podnosiła również kwestię finansowania kampanii „Solidarności”. Zdaniem krytyków obozu opozycji pieniężne wsparcie płynące z zagranicy miało być wyraźnym dowodem na to, że działacze Komitetów Obywatelskich realizują głównie interesy obcych państw, a suweren-

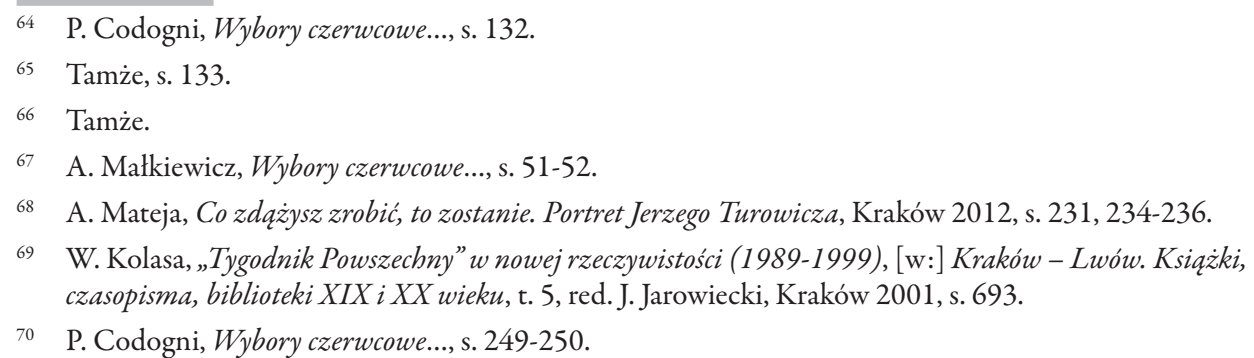


ność kraju jest zagrożona ${ }^{71}$. Niektóre środowiska dziennikarskie twierdziły wręcz, że kandydaci strony solidarnościowej to targowiczanie, którzy chca oddać Polskę w ajencje Busha lub Kobla72.

Ograniczony dostęp do środków masowego przekazu był ważnym czynnikiem kształtującym strategię wyborczą opozycji. Trudności z promowaniem kandydatów w radiu i telewizji zmusiły stronę solidarnościową do poszukiwania alternatywnych sposobów docierania do wyborców. Rozwiązaniem okazało się wykorzystanie reklamy wizualnej w formie plakatów i prowadzenie kampanii bezpośredniej.

Z punktu widzenia opozycji dużym wyzwaniem okazało się promowanie nieznanych dotąd działaczy. Rozwiązaniem tego problemu stało się tzw. zdjęcie z Wałęsą. Plakaty przedstawiające kandydatów w towarzystwie legendarnego przywódcy „Solidarności” miały uwiarygodnić poszczególnych kandydatów, a ponadto pozwalały zdezorientowanym wyborcom zidentyfikować stronę solidarnościową wśród dużej liczby osób ubiegających się o mandat ${ }^{73}$. Było to o tyle ważne, że zgodnie z ordynacją wyborczą na kartach do głosowania nie podawano informacji o przynależności partyjnej kandydata. $\mathrm{Na}$ potrzeby kampanii wyborczej w 1989 r. powstał również plakat nawiązujący do sceny z westernu $W$ samo potudnie ${ }^{74}$, a także niewielka grafika przedstawiająca polską flagę stopniowo wyłaniającą się z czerwonego tła ${ }^{75}$. Dużą popularnością cieszył się również plakat, na którym napis „Solidarność” przyjmował kształt zielonej kosy, zawisłej nad rozsianymi po łące czerwonymi kwiatami ${ }^{76}$.

Materiały wyborcze promujące kandydatów opozycji najczęściej przybierały formę plakatu, na którym widoczne było zbliżenie twarzy z zamieszczonym obok zwięzłym życiorysem i nieodłącznym biało-czerwonym symbolem „V"77. Dzięki energicznym działaniom wolontariuszy rozklejających plakaty wizerunki kandydatów „Solidarności” spotkać można było na każdym kroku na murach miejskich, przystankach, słupach ogłoszeniowych i w witrynach sklepów. Stosowano też zupełnie nowatorskie metody reklamy: w Krakowie i Łodzi po raz pierwszy do promocji wykorzystano tramwaje, w Kielcach oplakatowano taksówki należące do prywatnych przewoźników ${ }^{78}$. Po podkrakowskich miejscowościach jeżdżono białą , nyską" z wymiennymi panelami na dachu, zawierającymi nazwiska kandydatów. Rozdawano z niej plakaty, ulotki i gadżety, przez mikrofon nawoływano do udziału w wyborach i poparcia konkretnych działaczy ${ }^{79}$. Wykorzystywano

71 D. Rymar, Wybory z czerwca 1989 r. na Ziemi Lubuskiej - węztowe problemy w zarysie, [w:] „Ale nam się wydarzyto." Wybory 4 czerwca 1989 roku na Ziemi Lubuskiej we wspomnieniach parlamentarzystów i opracowaniach, red. M. Rusakiewicz, D. Rymar, Gorzów Wielkopolski 2014, s. 38-41.

72 Tamże, s. 40.

73 A. Małkiewicz, Wybory czerwcowe..., s. 50.

74 P. Codogni, Wybory czerwcowe..., s. 139.

75 G. Makiełło-Jarża, „Solidarność” dom twój zmieni, [w:] Wybory '89 w Krakowie..., s. 53.

76 Tamże, s. 51.

77 Tamże, s. 57.

78 P. Codogni, Wybory czerwcowe..., s. 155.

79 M. Osterwa-Czekaj, Wspominki propagandzistki, [w:] Wybory '89 w Krakowie..., s. 58. 
również „żywe postery” - wolontariuszy ubranych w kamizelki, na których odbijano nazwiska kandydatów i solidarnościowe symbole ${ }^{80}$.

Obok plakatów podstawowym narzędziem walki wyborczej były ulotki wyborcze. Ich wytwarzaniem zajmowały się profesjonalne drukarnie, jednak ze względu na ograniczone fundusze drukowano je również na powielaczach. Materiały wyborcze rozdawano w zakładach pracy, podczas spotkań z wyborcami i pod kościołami. Dystrybucja ulotek wymagała zaangażowania dużej liczby wolontariuszy - kolportażem materiałów zajmowali się listonosze, harcerze, młodzież szkolna, a nawet ministranci. Podstawową zasadą było wręczanie ulotek wyborcom, unikano wkładania ich do skrzynek pocztowych, przypadkowego rozrzucania na klatkach schodowych czy wkładania materiałów za wycieraczki samochodów ${ }^{81}$. Zgodnie z wytycznymi zawartymi w opozycyjnej instrukcji ulotki zawierały zdjęcia kandydatów wraz z życiorysem urzędowym, w którym poruszano też kwestie osobiste i związane z życiem rodzinnym. Koncentrowano się na informacjach o działalności opozycyjnej kandydata i jego wizji przyszłej działalności w parlamencie ${ }^{82}$. Uzupełnieniem działań promocyjnych była produkcja serii gadżetów z logiem „Solidarności”. Znaczki, torby, szklaneczki, nalepki, plakietki, reklamówki i notesy cieszyły się dużą popularnością wśród sympatyków Związku.

$\mathrm{Na}$ użytek czerwcowej kampanii wyborczej powstało wiele pomysłowych haseł wyborczych. Część z nich nawoływała jedynie do udziału w wyborach (hasła profrekwencyjne): „Nie śpij, bo cię przegłosują" ${ }^{\text {; }}$ „Udzielono Ci głosu - w sprawie Twojego losu”; „Już się nie opieraj - tym razem wybieraj”; ,Jak przodkowie do powstania, dzisiaj my do głosowania”; „Inni oddawali życie, byś mógł dzisiaj oddać głos”; „Wczoraj życie, dzisiaj głos pieczętuje Polski los" ${ }^{\text {". }}$. Większosć haseł bezpośrednio nawoływała do poparcia jednej z opcji. Do najpopularniejszych sloganów strony opozycyjnej należały: „Dobry komunista to skreślony komunista”; „Nie strzelać! Skreślać!”; „Ludzie Wałęsy zwalczają nonsensy”; „Solidarni górą - precz z nomenklaturą”; „Nie głosujesz przez lenistwo - oddasz mandat komunistom" ${ }^{\prime 5}$. Materiały wyborcze, których celem była prezentacja sylwetek opozycyjnych działaczy, wymagały tworzenia haseł indywidualnych. Sztaby wyborcze prześcigały się w tworzeniu krótkich, zapadających w pamięć sloganów: „My nie chcemy Uszatego, wybieramy Łapickiego”; „Lepsza przyszłość w naszych rękach głosujemy na Geremka”; „Dość nas robili w konia, głosujemy na Kuronia”; „Najlepszym posłem - niosą pogłoski - będzie dr Stefan Niesiołowski" ${ }^{86}$.

\footnotetext{
80 Tamże.

81 P. Codogni, Wybory czerwcowe..., s. 151-152.

82 Tamże, s. 153.

83 Wykaz popularnych haseł wyborczych, które wykorzystywane były w kampanii przez stronę opozycyjną, dostępny jest na stronie: Biblioteka Cyfrowa Ośrodka Karta, Spis haset wyborczych 1989 r., [online] http://dlibra.karta.org.pl/dlibra/docmetadata?id=8080\&from=publication, 25 III 2016. Zob. również W. Pawłowski, Czytanie murów, [w:] Polska wybory..., s. 111-118.

84 P. Codogni, Wybory czerwcowe..., s. 152.

85 Tamże.

86 Tamże, s. 153.
} 
Również na plakatach strony rządowej zamieszczano hasła mające zmobilizować wierny elektorat. Większość sloganów ukazywała PZPR jako gwaranta zgody, bezpieczeństwa i stabilności: „Różne zdania - jedna Polska”; „Polski skłóconej Europa nie chce”; „Spokój tak. Awanturom nie”; „Głosuj na program zgody narodowej”; „Nie pójdziemy naprzód z głową odwróconą wstecz". W hasłach tworzonych przez sztabowców koalicji widoczne było również dążenie do personalizacji wyborów. Slogany miały wywołać wrażenie, że walka toczy się pomiędzy konkretnymi ludźmi, a nie pomiędzy ruchami politycznymi: „Wybieraj ludzi, nie symbole”; „Wybieraj według zdolności, a nie przynależności”; „Bądź niezależny, wybierz najlepszego" ${ }^{77}$. Sztaby wyborcze strony rządowej utworzyły również serię sloganów wymierzonych w kandydatów „Solidarności”. Piętnowały one fakt, że część opozycjonistów starających się o mandat nie pochodziła z regionów, w których startowali ${ }^{88}$ : „Województwo ostrołęckie niech ten reprezentuje, kto w nim mieszka i w nim pracuje”; „Z Ursusa chcemy traktorów, a nie senatorów" 89 .

Istotnym elementem kampanii strony opozycyjnej stały się tzw. ściągi wyborcze. Były to wskazówki dotyczące sposobu głosowania. Instruowały, w jaki sposób uniknąć oddania głosu nieważnego. Wypisywano na nich jedynie nazwiska kandydatów obozu solidarnościowego. Zalecano skreślenie wszystkich nazwisk, które nie pojawiły się na „ściągawce”. Instrukcje rozprowadzano przy każdej możliwej okazji - na spotkaniach wyborczych, wiecach, w siedzibach Komitetów Obywatelskich, pod kościołami i w punktach informacyjnych na ulicach polskich miast. Procedura głosowania była skomplikowana, więc rozprowadzane materiały były ułatwieniem dla wyborców chcących oddać ważny głos.

Kluczowym elementem kampanii wyborczej „Solidarności” były bezpośrednie kontakty kandydatów z elektoratem. Kandydaci Komitetów Obywatelskich organizowali spotkania wyborcze nie tylko w większych miastach, ale i w małych miejscowościach. Było to możliwe dzięki wsparciu ze strony Kościoła, który udostępnił opozycji swoje struktury w regionach. Na parafialnych tablicach ogłoszeniowych umieszczano informacje o zebraniach z udziałem kandydatów oraz ich plakaty wyborcze. Po nabożeństwach wierni byli informowani o inicjatywach strony solidarnościowej i zachęcani do głosowania na „Solidarność”

87 Tamże, s. 223-224.

$88 \mathrm{~W}$ wielu regionach opozycja zmagała się z brakiem znanych, politycznie doświadczonych działaczy. Przyjęcie wspomnianego rozwiązania w założeniu miało stanowić formę wsparcia lokalnych struktur, choć „kandydaci przywożeni w teczkach” nie zawsze spotykali się z ciepłym przyjęciem miejscowych aktywistów. Zob. J. Król, Ku demokracji - 20 lat temu, [w:] Uprogu demokracji. Komitety Obywatelskie „Solidarnosic” Regionu Stupskiego w wyborach 4(18) czerwca 1989 roku. Materiaty z konferencji, Stupsk 5 VI 2009 r., red. M. Hejger, Słupsk 2010, s. 27-28; D. Iwaneczko, Opór spoteczny a wtadza w Polsce potudniowo-wschodniej 1980-1989, Warszawa 2005, s. 446-448.

P. Codogni, Wybory czerwcowe..., s. 223-224.

M. Gliwa, Na drodze do „końca historii”. Wybory parlamentarne w $1989 \mathrm{r}$. w województwie rzeszowskim, [w:] Wybory parlamentarne w 1989 r. w Polsce potudniowo-wschodniej, red. tenże, M. Krzysztofiński, Rzeszów 2011, s. 31. Więcej informacji na temat roli, jaką w kampanii 1989 r. odegrał Kościół, można odnaleźć w pracy: K. Koseła, Rola Kościota katolickiego w kampanii przed wyborami czerwcowymi, 
Spotkania wyborcze z kandydatami opozycyjnymi odbywały się w salkach parafialnych, placach przykościelnych, remizach strażackich, klubach osiedlowych, domach kultury, kinach i teatrach, na rynkach miast, w zakładach pracy, parkach miejskich, a nawet na stadionach sportowych ${ }^{11}$. Zgromadzenia organizowane przez opozycję cieszyły się dużą popularnością. Na spotkaniach z wyborcami pojawiali się wszyscy kandydaci Komitetów Obywatelskich z danego okręgu - dzięki temu osiągano większą frekwencję niż na spotkaniach indywidualnych, podkreślając równocześnie jedność „drużyny Wałęsy"22. Publiczność przyciągnąć miała również obecność znanych z mediów konferansjerów i artystów ${ }^{93}$.

Większość spotkań z kandydatami „Solidarności” przebiegała według ściśle określonego scenariusza. Ważnym punktem było instruowanie zebranych, w jaki sposób oddać ważny głos w wyborach. Po takim wstępie kandydaci mieli czas na przedstawienie swoich dokonań, poglądów i programu wyborczego. W wypowiedziach nawiązywali do problemów istotnych dla mieszkańców danego regionu i podkreślali swoje związki z okręgiem. Prezentacje osób starających się o mandat były przeplatane występami gwiazd filmu i estrady. Następnym, bardzo ważnym punktem każdego spotkania była dyskusja i czas na pytania do kandydatów ${ }^{94}$. Możliwość debaty wprowadzała do spotkań dynamizm i ożywienie. Było to zupełne novum dla wyborców, przyzwyczajonych do długich i nieciekawych przemówień partyjnych towarzyszy. Podczas zebrań przedwyborczych kandydaci opozycyjni nie unikali kwestii trudnych. Podkreślali nieuchronność likwidacji nierentownych zakładów pracy, odpowiadali też na pytania o podziały w opozycji. W spotkaniach z udziałem opozycji uczestniczyli też kandydaci popierani przez PZPR. Często była to dla nich jedyna szansa na autoprezentację. Starali się zadawać kandydatom „Solidarności” niewygodne pytania ${ }^{95} \mathrm{i}$ wciągać ich w utarczki słowne, próbując zakłócić w ten sposób przebieg zebrania ${ }^{96}$.

Spotkania wyborcze organizowane przez kandydatów popieranych przez PZPR spotkały się z nikłym zainteresowaniem wyborców. Organizowano je zgodnie ze starymi wzorcami - ich oprawa była mało atrakcyjna. Ograniczała się zazwyczaj do występów lokalnych zespołów ludowych. Podczas zebrań kandydaci odczytywali swój program z kartek, nie przewidywano czasu na pytania od zgromadzonych słuchaczy ${ }^{97}$.

[w:] Wyniki badań - wyniki wyborów, 4 czerwca 1989, red. L. Kolarska-Bobińska, P. Łukasiewicz, Z. W. Rykowski, Warszawa 1990, s. 95-141.

91 M. Bukała, Wybory parlamentarne w 1989 r. w województwie tarnobrzeskim, [w:] Wybory parlamentarne w 1989 r. $w$ Polsce..., s. 131.

92 P. Codogni, Wybory czerwcowe..., s. 143.

93 Tamże.

94 M. Bukała, Wybory parlamentarne..., s. 131-132.

95 Listę dwudziestu drażliwych pytań opracowanych przez Departament III MSW przywołał Rafał Reczek. Zob. R. Reczek, Reakcja lokalnych wtadz i spoteczeństwa Wielkopolski na rozwój wydarzeń w 1989 roku, [w:] Krok ku wolności. Wybory czerwcowe 1989 i ich konsekwencje, red. K. Białecki, S. Jankowiak, R. Reczek, Poznań 2015, s. 111.

96 P. Codogni, Wybory czerwcowe..., s. 149.

97 Tamże, s. 213. 
Nieatrakcyjna forma spotkań zaowocowała niską frekwencją, dlatego partia musiała uciekać się do organizacji zebrań na terenie zakładów. Innym działaniem profrekwencyjnym było prowadzenie sprzedaży artykułów deficytowych podczas organizowanych zgromadzen $^{98}$. PZPR próbowała wykorzystać w kampanii odbywające się w tym czasie imprezy, jednak skuteczność takich działań była wątpliwa ${ }^{99}$.

Analiza kanałów, jakimi rywalizujące strony starały się dotrzeć do wyborców, wskazuje, że kampania 1989 r. wpisuje się w model kampanii w stylu premodernizacyjnym. Strona rządowa starała się ograniczyć obecność opozycji w mediach masowych. Utrudnienia w dostępie do programów telewizyjnych spowodowały, że obóz solidarnościowy komunikował się ze swoim elektoratem głównie za pomocą prasy. Świadomi ograniczeń tego medium, kandydaci starali się położyć większy nacisk na bezpośredni kontakt z elektoratem oraz organizowanie atrakcyjnych pod względem treści i formy spotkań publicznych. Strona koalicyjno-rządowa nie miała problemów z dostępem do środków masowego przekazu. Do swoich wyborców docierała za pośrednictwem radia, telewizji i prasy. Obecność w mediach masowych połączono z terenowymi spotkaniami wyborczymi, jednak z reguły nie miały one atrakcyjnej formy ${ }^{100}$.

\section{UMIEJSCOWIENIE ELEKTORATU}

Źródłem taktyki strony opozycyjnej było przekonanie o konieczności zachowania jedności w obozie solidarnościowym. Raciborski zauważa, że cechą charakterystyczną działań „Solidarności” była swoista depersonalizacja kandydatów - wszyscy działacze tworzyli zwartą, zgodną ekipę, wspierającą się podczas kampanii ${ }^{101}$. Działaczy znajdujących się na listach opozycji szybko zaczęto określać mianem „drużyny Wałęsy”. Starano się maksymalnie uprościć decyzję wyborców - sprowadzić ją do wyboru między „Solidarnością” a obozem komunistycznym. Większą wagę przywiązywano więc do politycznego zaplecza kandydatów i ich przeszłości, natomiast kwestia programu wyborczego pozostawała na dalszym planie. Jak zauważył Andrzej Lipiński, kandydaci PZPR starali się stosować socjotechnikę mimikry. Chcąc pozbyć się piętna „ludzi nomenklatury", na plakatach wyborczych nie zamieszczali symboli, które mogłyby zdradzić ich partyjną przynależnośćc1 ${ }^{102}$. Kandydaci popierani przez ówczesną władzę próbowali odwrócić niekorzystne dla siebie tendencje, dążąc do personalizacji wyborów i wywołania wrażenia, że walka wyborcza toczy się pomiędzy konkretnymi ludźmi o różnych przymiotach, a nie pomiędzy dwoma przeciwstawnymi ruchami politycznymi ${ }^{103}$.

\footnotetext{
98 Tamże, s. 214-215.

100 Opis przebiegu jednej z partyjnych konwencji wyborczych zob. M. Henzler, Konwencja, [w:] Polska wybory..., s. 141-144.

101 J. Raciborski, Polskie wybory..., s. 32.

102 A. Lipiński, Plebiscyt i odmowa..., s. 190.

103 J. Raciborski, Polskie wybory..., s. 32.
} 
Nieskuteczność działań strony rządowej jednoznacznie wykazały powyborcze analizy zachowań wyborczych. Wynika z nich, że podstawową determinantą decyzji wyborczej była właśnie przynależność partyjna kandydata, a nie jego cechy indywidualne ${ }^{104}$. Nawet w tych wypadkach, w których poszczególni kandydaci PZPR uzyskali stosunkowo wysoki procent gtosów, byto to następstwem określonej orientacji politycznej przez nich reprezentowanej, z reguty proreformatorskiej - oceniał Małkiewicz ${ }^{105}$. Zmyślna taktyka sztabowców strony rządowej nie przyniosła zatem zakładanych rezultatów, co może sugerować, że nie do końca przystawała ona do sposobu, w jaki ówczesny polski wyborca postrzegał politykę i samych polityków. Należy mieć na uwadze, że procesy modernizacji, indywidualizacji, mediatyzacji i personalizacji polityki nie były wówczas w Polsce tak zaawansowane, jak w społeczeństwach zachodnioeuropejskich ${ }^{106}$. Argumenty wysuwane przez obóz rządzący nie trafiały więc na podatny grunt.

Kampanijne działania strony rządowej obliczone były głównie na podtrzymanie twardego elektoratu. Jego rdzeń stanowili ludzie tworzący szeroko pojęty aparat władzy oraz ta część klasy robotniczej, która nie kontestowała ówczesnego systemu ${ }^{107}$. Obóz solidarnościowy zdołał pozyskać znaczną część głosów osób wahających się, jednak jego sztab wyborczy zdawał sobie sprawę z konieczności mobilizowania własnego elektoratu ${ }^{108}$. Społeczną apatię przełamać miały liczne odezwy hierarchów kościelnych, zamieszczane na łamach opozycyjnej prasy, w których piętnowano obywatelską bezczynność i zachęcano do aktywnego uczestnictwa w wyborach. Jak zauważył Sergiusz Kowalski: $w$ tej dziwnej kampanii cześciej bodaj niż „gtosuj na nas" padato wezwanie „nie bądź bierny"109.

$104 \mathrm{Na}$ wagę przynależności partyjnej zwracał uwagę m.in. Leszek Miller. Zob. L. Miller, Anatomia sity, rozm. R. Krasowski, Warszawa 2013, s. 13.

105 A. Małkiewicz, Wybory czerwcowe..., s. 36.

106 Zob. D. Piontek, Personalizacja rywalizacji wyborczej w kampanii parlamentarnej, „Roczniki Nauk Społecznych” 2012, vol. 4 (40), nr 3, s. 110; taż, Personalizacja jako efekt mediatyzacji polityki, „Środkowoeuropejskie Studia Polityczne” 2015, nr 3, s. 91-103, [online] DOI: 10.14746/ ssp.2015.3.5; I. McAllister, Personalizacja polityki, [w:] Zachowania polityczne, t. 2, red. R. J. Dalton, H.-D Klingemann, red. nauk. wyd. pol. R. Markowski, przeł. A. Brzóska i in., Warszawa 2010, s. 173-194; E. Marciniak, Personalizacja zachowań wyborczych w Polsce w kontekście Modelu Zgodności Preferencji Politycznych, Warszawa 2013; P. Potocki, Zjawisko personalizacji postrzegania rzadu w Polsce w latach 1997-2007: wybrane aspekty, „Zeszyty Naukowe” (AlmaMer Wyższa Szkoła Ekonomiczna) 2011, z. 2 (64), s. 75-98.

107 A. Lipiński, Plebiscyt i odmowa..., s. 177, 181.

108 Zob. B. Geremek, J. Żakowski, Rok 1989. Bronistaw Geremek opowiada, Jacek Żakowski pyta, Warszawa 1990, s. 163. Wątpliwości co do mobilizacyjnych zdolności haset wysuwanych przez opozycję towarzyszyły m.in. Janowi Rokicie. Zob. J. Rokita, Anatomia przypadku, rozm. R. Krasowski, Warszawa 2013, s. 21.

109 S. Kowalski, Narodziny III Rzeczypospolitej, s. 16. 


\section{ROLA PODMIOTÓW ZEWNĘTRZNYCH I FINANSOWANIE KAMPANII}

W walkę wyborczą po stronie „Solidarności” zaangażowały się dwie ekipy francuskich specjalistów do spraw marketingu politycznego. W'śód nich znalazł się Jacques Séguéla, współzałożyciel agencji reklamowej RSCG (Havas-Advertising), doradca francuskiego prezydenta François Mitterranda. Na potrzeby kampanii Séguéla stworzył plakat przestawiający Wałęsę w zielonych okularach, stanowiących przeciwieństwo czarnych okularów Jaruzelskiego ${ }^{110}$. Francuscy specjaliści zaproponowali, aby okulary w kolorze nadziei uczynić symbolem całej kampanii, jednak pomysł nie spotkał się z akceptacją polskich sztabowców. Współpraca między sztabem solidarnościowym a doradcami francuskimi bywa różnie oceniana: Edmund Wnuk-Lipiński określił konsultacje jako spotkania ludzi z podziemia z ludźmi z księżyca, stwierdzając, że koncepty zachodnich specjalistów były zbyt oderwane od polskiej rzeczywistości ${ }^{111}$. Choć środowisko opozycyjne korzystało z pomocy wyspecjalizowanych agencji, to czyniło to w niewielkim stopniu - ostatnie słowo zawsze należało do liderów ruchu i samych kandydatów. Przywódcy „Solidarności” zdawali sobie sprawę, że to na nich spoczywa odpowiedzialność za charakter i ostateczny wynik prowadzonej kampanii ${ }^{112}$.

Podczas kampanii wyborczej strona solidarnościowa zdecydowała się wykorzystać szerokie poparcie krajowych autorytetów oraz znanych postaci z zagranicy. Sympatię dla ruchu publicznie manifestowały gwiazdy światowego formatu. Jane Fonda, Nastassja Kinski, Carole Bouquet i Grace Jones pozowały do zdjęć ze znaczkami „Solidarności”. 27 maja amerykański wokalista Stevie Wonder odwiedził biuro wyborcze „Solidarności” mieszczące się w kawiarni Niespodzianka przy placu Konstytucji. Tam wraz z Jackiem Kuroniem i Janem Lityńskim zaśpiewał swój wielki przebój I just called to say I love you. W kampanii opozycji aktywnie uczestniczył również znany francuski aktor i piosenkarz Yves Montand, pomysłodawca społecznej inicjatywy „Wybory bez granic” ${ }^{113}$. Na łamach „Le Figaro” apelował o pomoc dla polskiej opozycji - nawoływał do przesyłania pieniędzy, sprzętu drukarskiego i radiowego oraz zapasów papieru. Swoje poparcie manifestowal podczas spotkania ze studentami na Uniwersytecie Warszawskim oraz na wiecach przedwyborczych w Zabrzu, Gliwicach, Legnicy i Jeleniej Górze ${ }^{114}$. Istotnym wydarzeniem była wizyta Zbigniewa Brzezińskiego, doradcy prezydenta USA Jimmy'ego Cartera do spraw bezpieczeństwa narodowego. Wyraził on przekonanie o nadchodzącym zwycięstwie opozycji, co spotkało się z ostrymi re-

\footnotetext{
110 P. Codogni, Wybory czerwcowe..., s. 132.

111 Tamże.

112 Zob. L. Wałęsa, Droga do wolności. Decydujace lata 1985-1990, Warszawa 1991, s. 138-143; J. Kuroń, J. Żakowski, PRL dla początkujacych, Wrocław 1995, s. 268.

113 P. Pleskot, „Nie wyrzucać socjalizmu za okno”. Francja wobec wyborów czerwcowych 1989 r., [w:] Wybory i referenda w PRL, s. 776.

114 P. Codogni, Wybory czerwcowe..., s. 146.
} 
akcjami oficjalnej prasy ${ }^{115}$. Również spotkanie Bronisława Geremka z wiceprezydentem Danem Quayle'em w Waszyngtonie zostało odebrane jako manifestacja amerykańskiego poparcia dla „Solidarności” ${ }^{116}$. Duże znaczenie dla kampanii opozycji miało też kwietniowe spotkanie Wałęsy, Mazowieckiego i Geremka z papieżem Janem Pawłem II w Watykanie ${ }^{117}$.

Strona rządowa sięgnęła po doświadczenia kampanijne zachodnich demokracji. Organy centralne zadecydowały o powołaniu specjalnego sztabu odpowiedzialnego za stworzenie analiz wyborów w państwach zachodnich. W skład zespołu wchodzili prawnicy, dziennikarze, socjologowie, psychologowie społeczni, przedstawiciele Ośrodka Badań Opinii Publicznej, Centrum Badania Opinii Społecznej oraz dyplomaci z doświadczeniem w kampaniach wyborczych na Zachodzie ${ }^{118}$. Szczegółowej analizie poddano również program wyborczy „Solidarności”. W celach instruktażowych przeprowadzano symulacje spotkań wyborczych z udziałem opozycji. Przebieg symulacji utrwalano na taśmach, które następnie przesyłano do komitetów wojewódzkich doradzających kandydatom strony rządowej ${ }^{119}$.

Przedstawiciele aparatu partyjnego mieli do dyspozycji o wiele większe zasoby materialne i personalne. Szacuje się, że PZPR przeznaczyła na działania kampanijne aż

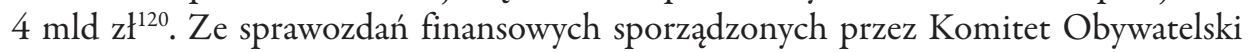
wynika, że wydatki na kampanię opozycji wyniosły około $2 \mathrm{mld}$ zł, przy czym najpoważniejszym kosztem była produkcja plakatów i ulotek (ponad $1 \mathrm{mld}$ zł) ${ }^{121}$. Zbudowanie zaplecza finansowego od podstaw było dla opozycji nie lada wyzwaniem. Władze „Solidarności” postanowiły skorzystać z ofiarności społeczeństwa. W apelu z 28 kwietnia 1989 r. Wałęsa zachęcał Polaków do zakupu „cegiełek” o nominałach 500, 1 tys. i 5 tys. zł. Dochód z ich sprzedaży zasilał fundusz wyborczy solidarnościowej opozycji. Dodatkowo podano numery kont bankowych, na które można było dokonywać wpłat z Polski i z zagranicy ${ }^{122}$. Niekiedy pomocy udzielano w dość zaskakujących formach, np. były przewodniczący Sōhyō, federacji japońskich związków zawodowych, w ra-

115 Tamże, s. 147.

116 Mimo wielu symbolicznych gestów poparcia dla opozycji władze amerykańskie bardzo powściągliwie podchodziły do demokratycznych przemian zachodzących w Polsce. Zaskakujące zwycięstwo „Solidarności” wzbudziło zaniepokojenie zachodnich dyplomatów, którzy obawiając się ostrej kontrreakcji obozu komunistycznego, starali się studzić społeczne nastroje i wskazywali na konieczność realizacji okrągłostołowych porozumień. Podobną, bardzo ostrożną postawę przyjęły władze francuskie. Zob. J. Tyszkiewicz, Stany Zjednoczone wobec wyborów w Polsce (1947-1957-1989), [w:] Wybory i referenda w PRL, s. 765-773; P. Pleskot, „Nie wyrzucać socjalizmu..., s. 775-787; M. Mikołajczyk, Państwa zachodnie wobec rozmów Okragtego Stotu i wyborów czerwcowych w Polsce w 1989 roku, [w:] Krok ku wolności..., s. 161-193.

117 P. Codogni, Wybory czerwcowe..., s. 160.

118 Tamże, s. 202.

119 Tamże, s. 203.

120 D. Stola, Finanse PZPR w jej ostatnich latach, „Więź” 2000, nr 3, s. 132.

121 Finanse Ogólnopolskiego Biura Wyborczego Komitetu Obywatelskiego „Solidarnośc”, [w:] Wybory 1989. Dokumenty..., s. 287.

122 Tamże, s. 278. 
mach wsparcia działań kampanijnych przesłał do Polski kontener chłodniczy zawierający dwie tony mrożonego mięsa ${ }^{123}$.

\section{PODSUMOWANIE}

Przeprowadzona analiza wskazuje, że działania sztabowców opozycji oraz strony rządowej wpisują się w model kampanii typu premodernizacyjnego. Po pierwsze, w kampanii przed „wyborami kontraktowymi” mieliśmy do czynienia z wysokim stopniem decentralizacji działań wyborczych. Sposób formowania list kandydatów, który zastosowała opozycja, ukazuje wagę i kreacyjną rolę struktur lokalnych, cieszących się dużą swobodą działania. Wszelkie zadania kampanijne były realizowane głównie przez członków „Solidarności”, wolontariuszy i kandydatów. Wysoki stopień decentralizacji widoczny był również u strony koalicyjnej, która nie była w stanie ograniczyć wewnątrzpartyjnej rywalizacji i nie zdołała zapobiec zjawisku rozproszenia głosów. Po drugie, kampania prowadzona przez obie strony była krótka, spontaniczna i bardzo intensywna. Przygotowania do starcia wyborczego miały charakter krótkoterminowy, przez co obie kampanie sprawiały wrażenie niedopracowanych i chaotycznych. Po trzecie, w sztabach obu stron wiele decyzji podejmowano naprędce, głównie na podstawie intuicji i osobistych doświadczeń aktorów politycznych, brakowało bowiem pogłębionych analiz i systematycznie przeprowadzanych badań opinii publicznej. Po czwarte, choć oba obozy korzystały z pomocy wyspecjalizowanych agencji i zewnętrznych konsultantów, to czyniły to w niewielkim stopniu, a ostateczna decyzja zawsze należała do struktur partyjnych lub związkowych, a także do samych kandydatów. Zarówno przywódcy „Solidarności”, jak i liderzy strony rządzącej zdawali sobie sprawę, że to na nich właśnie spocznie odpowiedzialność za charakter i wynik prowadzonej kampanii. Po piąte, obóz solidarnościowy komunikował się ze swoim elektoratem głównie za pomocą prasy. Ograniczenia tego medium spowodowały, że kandydaci opozycji musieli położyć większy nacisk na bezpośredni kontakt z wyborcami oraz organizowanie atrakcyjnych pod względem treści i formy spotkań publicznych. Strona koalicyjna nie miała podobnych problemów. Obecność w mediach masowych starano się łączyć z terenowymi spotkaniami wyborczymi, jednak z reguły nie cieszyły się one dużą frekwencją. Po szóste, kampanijne działania strony rządowej oraz obozu solidarnościowego obliczone były głównie na podtrzymanie twardego elektoratu i mobilizację wyborców.

Charakterystyczna była rola kandydata w kampanii. Przynależność do opozycji lub obozu rządowego znalazła się na pierwszym planie. Widać tu główną różnicę między kampanią 1989 r. a obecnymi wyborami w stylu modernizacyjnym, w których dąży się do jak największej personalizacji. Strona koalicyjna starała się odwrócić tę niekorzystną dla siebie tendencję. Z kolei obóz solidarnościowy starał się wykorzystać ją podczas tworzenia kampanijnej strategii. Nieustanne eksponowanie marki związku oraz

123 P. Codogni, Wybory czerwcowe..., s. 121. 
uczynienie Lecha Wałęsy twarzą własnej kampanii częściowo rozwiązywało problem niskiej rozpoznawalności kandydatów i braku czasu koniecznego do przeprowadzenia skutecznych działań promocyjnych.

\section{BIBLIOGRAFIA}

\section{Materiały drukowane:}

\section{Literatura źródłowa:}

- monografie i opracowania:

Ash T. G., Wiosna obywateli. Rewolucja 1989 widziana w Warszawie, Budapeszcie, Berlinie i Pradze, przeł. A. Husarska, Londyn 1990.

Geremek B., Żakowski J., Rok 1989. Bronistaw Geremek opowiada, Jacek Żakowski pyta, Warszawa 1990.

Miller L., Anatomia sity, rozm. R. Krasowski, Warszawa 2013.

Rokita J., Anatomia przypadku, rozm. R. Krasowski, Warszawa 2013.

Kuroń J., Żakowski J., PRL dla początkujacych, Wrocław 1995.

Wałęsa L., Droga do wolności. Decydujące lata 1985-1990, Warszawa 1991.

- rozdziały w pracach zbiorowych:

Ash T. G., Polskie problemy, [w:] Polska wybory '89, red. R. Kałuża, Warszawa 1989.

Bratkowski S., Gramy o swój los, [w:] Polska wybory '89, red. R. Kałuża, Warszawa 1989.

Finanse Ogólnopolskiego Biura Wyborczego Komitetu Obywatelskiego „Solidarnośc”, [w:] Wybory 1989. Dokumenty strony solidarnościowo-opozycyjnej, t. 1: Kwatera Gtówna, red. I. Słodkowska, Warszawa 2009.

Henzler M., Konwencja, [w:] Polska wybory '89, red. R. Kałuża, Warszawa 1989.

Janicki A., Beczka radości i kilka tyżek dziegciu, [w:] Wybory '89 w Krakowie. Wspomnienia, relacje i dokumenty z kampanii wyborczej Matopolskiego Komitetu Obywatelskiego „Solidarność, red. T. Gąsowski, Kraków 1999.

Jerzy Urban, [w:] Koniec epoki. Wywiady Maksymiliana Berezowskiego, red. M. Berezowski, Warszawa 1991.

Kowalski P., Proponowano nadzieję, [w:] Nasze 53 dni i dwa tygodnie. 4 czerwca '89, red. I. Śledzińska-Katarasińska, M. Sondej, Łódź 2009.

Kowalski P., To miasto Eódź się nazywa, [w:] Nasze 53 dni i dwa tygodnie. 4 czerwca '89, red. I. Śledzińska-Katarasińska, M. Sondej, Łódź 2009.

KrólJ., Ku demokracji-20 lat temu, [w:] Uprogudemokracji. Komitety Obywatelskie „Solidarnośc” Regionu Stupskiego w wyborach 4(18) czerwca 1989 roku. Materiaty z konferencji, Stupsk 5 VI 2009 r., red. M. Hejger, Słupsk 2010.

Łobodziński W., Bytem szefem zespotu promocyjnego na Mokotowie, [w:] Polska wybory '89, red. R. Kałuża, Warszawa 1989.

Makiełło-Jarża G., „Solidarnośc'” dom twój zmieni, [w:] Wybory '89 w Krakowie. Wspomnienia, relacje i dokumenty z kampanii wyborczej Matopolskiego Komitetu Obywatelskiego „Solidarność, red. T. Gąsowski, Kraków 1999. 
Marian Orzechowski, [w:] Koniec epoki. Wywiady Maksymiliana Berezowskiego, red. M. Berezowski, Warszawa 1991.

Osterwa-Czekaj M., Wspominki propagandzistki, [w:] Wybory '89 w Krakowie. Wspomnienia, relacje i dokumenty zkampanii wyborczej Matopolskiego Komitetu Obywatelskiego „Solidarnośc”, red. T. Gąsowski, Kraków 1999.

Pawłowski W., Czytanie murów, [w:] Polska wybory '89, red. R. Kałuża, Warszawa 1989.

Wojciech Jaruzelski, [w:] Koniec epoki. Wywiady Maksymiliana Berezowskiego, red. M. Berezowski, Warszawa 1991.

\section{Literatura pomocnicza:}

- monografie i opracowania:

Andrusiewicz A., Polska 1980-1990. Kalendarz dekady przetomu, Rzeszów 1995.

Borowiec P., Czas polityczny po rewolucji. Czas w polskim dyskursie politycznym po 1989 roku, Kraków 2013.

Chruściak R., System wyborczy i wybory w Polsce 1989-1998. Parlamentarne spory i dyskusje, Warszawa 1999.

Codogni P., Wybory czerwcowe 1989 roku. Uprogu przemiany ustrojowej, Warszawa 2012.

Dobek-Ostrowska B., Porozumienie czy konflikt. Politycy, media i obywatele w komunikowaniu politycznym. Propaganda i PR w polityce, kampanie wyborcze, marketing i reklama polityczna, Warszawa 2009.

Dudek A., Historia polityczna Polski 1989-2012, Kraków 2013.

Dudek A., Reglamentowana rewolucja. Rozktad dyktatury komunistycznej w Polsce 1988-1990, Kraków 2004.

Ignaczewski G., Specyfika marketingu politycznego w Polsce, Toruń 2005.

Iwaneczko D., Opór spoteczny a wtadza w Polsce potudniowo-wschodniej 1980-1989, Warszawa 2005.

Kolczyński M., Sztumski J., Marketing polityczny. Ksztattowanie indywidualnych i zbiorowych opinii, postaw i zachowań, Katowice 2003.

Kowalski S., Narodziny III Rzeczypospolitej, Warszawa 1996.

Lipiński A., Plebiscyt i odmowa. Studium terenowe reakcji wyborczej 1989 roku, Warszawa 1990.

Małkiewicz A., Wybory czerwcowe 1989, Warszawa 1994.

Marciniak E., Personalizacja zachowań wyborczych w Polsce w kontekście Modelu Zgodności Preferencji Politycznych, Warszawa 2013.

Mateja A., Co zdążysz zrobić, to zostanie. Portret Jerzego Turowicza, Kraków 2012.

Nieć M., Komunikowanie polityczne w nowoczesnym państwie, Warszawa 2013.

Norris P., A virtuous circle. Political communications in postindustrial societies, Cambridge 2000.

Norris P., Electoral change in Britain since 1945, Oxford 1997.

Paczkowski A., Od sfatszowanego zwycięstwa do prawdziwej kleski. Szkice do portretu PRL, Kraków 1999.

Piasecki A., Wybory w Polsce 1989-2011, Kraków 2012.

Raciborski J., Polskie wybory. Zachowania wyborcze spoteczeństwa polskiego 1989-1995, Warszawa 1997. 
Wiszniowski R., Marketing wyborczy. Studium kampanii wyborczych w systemach prezydenckich i semiprezydenckich (Finlandia, Francja, Polska, Stany Zjednoczone), Warszawa-Wrocław 2000.

- rozdziały w pracach zbiorowych:

Astramowicz-Leyk T., Kampania wyborcza 1989 roku, [w:] Polska - 25 lat transformacji systemowej. Polityka, gospodarka, bezpieczeństwo, red. taż, W. Tomaszewski, Olsztyn 2014.

Bukała M., Wybory parlamentarne w 1989 r. w województwie tarnobrzeskim, [w:] Wybory parlamentarne w 1989 r. w Polsce potudniowo-wschodniej, red. M. Gliwa, M. Krzysztofiński, Rzeszów 2011.

Dobek-Ostrowska B., Profesjonalizacja kampanii wyborczych, [w:] Kampania wyborcza. Marketingowe aspekty komunikowania politycznego, red. taż, Wrocław 2005.

Dudek A., Decydujące miesiące. Polska, kwiecień-sierpień 1989, [w:] Polska 1986-1989: koniec systemu. Materiaty międzynarodowej konferencji, Miedzeszyn 21-23 października 1999, t. 1: Referaty, red. P. Machcewicz, Warszawa 2002.

Dziuba A., Kampania wyborcza i wybory w województwie katowickim, [w:] Upadek systemu komunistycznego na Górnym Ślasku. Wokót przemian 1989 roku w województwach katowickim i opolskim, red. tenże, S. Rosenbaum, Katowice 2010.

Farrell D. M., Campaign strategies and tactics, [w:] Comparing democracies. Elections and voting in global perspective, red. L. LeDuc, R. Niemi, P. Norris, Thousand Oaks 1996.

Farrell D. M., Webb P., Political parties as campaign organizations, [w:] Parties without partisans. Political change in advanced industrial democracies, red. R. Dalton, M. Wattenberg, Oxford 2000.

Gliwa M., Na drodze do „końca historii”. Wybory parlamentarne w 1989 r. w województwie rzeszowskim, [w:] Wybory parlamentarne w 1989 r. w Polsce potudniowo-wschodniej, red. tenże, M. Krzysztofiński, Rzeszów 2011.

Kolasa W., „Tygodnik Powszechny” w nowej rzeczywistości (1989-1999), [w:] Kraków - Lwów. Ksiązki, czasopisma, biblioteki XIX i XX wieku, t. 5, red. J. Jarowiecki, Kraków 2001.

Koseła K., Rola Kościota katolickiego w kampanii przed wyborami czerwcowymi, [w:] Wyniki badań - wyniki wyborów, 4 czerwca 1989, red. L. Kolarska-Bobińska, P. Łukasiewicz, Z. W. Rykowski, Warszawa 1990.

McAllister I., Personalizacja polityki, [w:] Zachowania polityczne, t. 2, red. R. J. Dalton, H.-D. Klingemann, red. nauk. wyd. pol. R. Markowski, przeł. A. Brzóska i in., Warszawa 2010.

Mikołajczyk M., Państwa zachodnie wobec rozmów Okragtego Stotu i wyborów czerwcowych w Polsce w 1989 roku, [w:] Krok ku wolności. Wybory czerwcowe 1989 i ich konsekwencje, red. K. Białecki, S. Jankowiak, R. Reczek, Poznań 2015.

Pleskot P., „Nie wyrzucać socjalizmu za okno”. Francja wobec wyborów czerwcowych 1989 r., [w:] Wybory i referenda w PRL, red. S. Ligarski, M. Siedziako, Szczecin 2014.

Reczek R., Reakcja lokalnych wtadz i spoteczeństwa Wielkopolski na rozwój wydarzeń w 1989 roku, [w:] Krok ku wolności. Wybory czerwcowe 1989 i ich konsekwencje, red. K. Białecki, S. Jankowiak, R. Reczek, Poznań 2015.

Rosenbaum S., Miejskie struktury PZPR województwa katowickiego wobec wyborów czerwcowych 1989 r., [w:] Wybory i referenda w PRL, red. S. Ligarski, M. Siedziako, Szczecin 2014.

Rymar D., Wybory z czerwca 1989 r. na Ziemi Lubuskiej - węztowe problemy w zarysie, [w:] „Ale nam sie wydarzyto". Wybory 4 czerwca 1989 roku na Ziemi Lubuskiej we wspomnieniach 
parlamentarzystów i opracowaniach, red. M. Rusakiewicz, D. Rymar, Gorzów Wielkopolski 2014.

Słodkowska I., Organizacja strony solidarnościowo-opozycyjnej w kampanii wyborczej 1989 roku, [w:] Wybory 1989. Dokumenty strony solidarnościowo-opozycyjnej, t. 1: Kwatera Gtówna, taż, Warszawa 2009.

Tyszkiewicz J., Stany Zjednoczone wobec wyborów w Polsce (1947-1957-1989), [w:] Wybory i referenda $w$ PRL, red. S. Ligarski, M. Siedziako, Szczecin 2014.

Wiszniowski R., Modernizacja kampanii politycznej na przyktadzie parlamentarnych kampanii wyborczych w Polsce z lat dziewięćdziesiatych, ze szczególnym uwzględnieniem PSL, [w:] $W$ kregu historii i politologii. Ksiega jubileuszowa dedykowana Profesorowi Stanistawowi Dąbrowskiemu, red. K. Dziubka i in., Wrocław 2002.

- artykuły w czasopismach naukowych:

Dudek A., Kryzys systemu komunistycznego w Polsce lat osiemdziesiątych, „Pamięć i Sprawiedliwość" 2007, nr 1 (11).

Garlicki J., Komunikowanie polityczne - od kampanii wyborczej do kampanii permanentnej, „Studia Politologiczne” 2010, vol. 16.

Piontek D., Personalizacja jako efekt mediatyzacji polityki, „Środkowoeuropejskie Studia Polityczne" 2015, nr 3, [online] DOI: 10.14746/ssp.2015.3.5.

Piontek D., Personalizacja rywalizacji wyborczej w kampanii parlamentarnej, „Roczniki Nauk Społecznych" 2012, vol. 4 (40), nr 3.

Potocki P., Zjawisko personalizacji postrzegania rzadu w Polsce w latach 1997-2007: wybrane aspekty, „Zeszyty Naukowe” (AlmaMer Wyższa Szkoła Ekonomiczna) 2011, z. 2 (64).

Sokala A., Wybory parlamentarne - czerwiec 1989 r., „Przegląd Sejmowy” 2009, nr 3 (92).

- artykuły prasowe:

Stola D., Finanse PZPR w jej ostatnich latach, „Więź” 2000, nr 3.

\section{Materiały elektroniczne:}

Literatura źródłowa:

Biblioteka Cyfrowa Ośrodka Karta, Spis haset wyborczych 1989 r., [online] http://dlibra.karta. org.pl/dlibra $/$ docmetadata?id=8080\&from=publication.

Katarzyna GŁOWACKA - studentka politologii w Instytucie Nauk Politycznych i Stosunków Międzynarodowych Uniwersytetu Jagiellońskiego (II rok studiów II stopnia). Interesuje się głównie kwestiami masowych naruszeń praw człowieka, socjologią zbiorowej przemocy, a także działalnością negacjonistów Holocaustu. 